American Journal of

Supply Chain Management

(AJSCM)

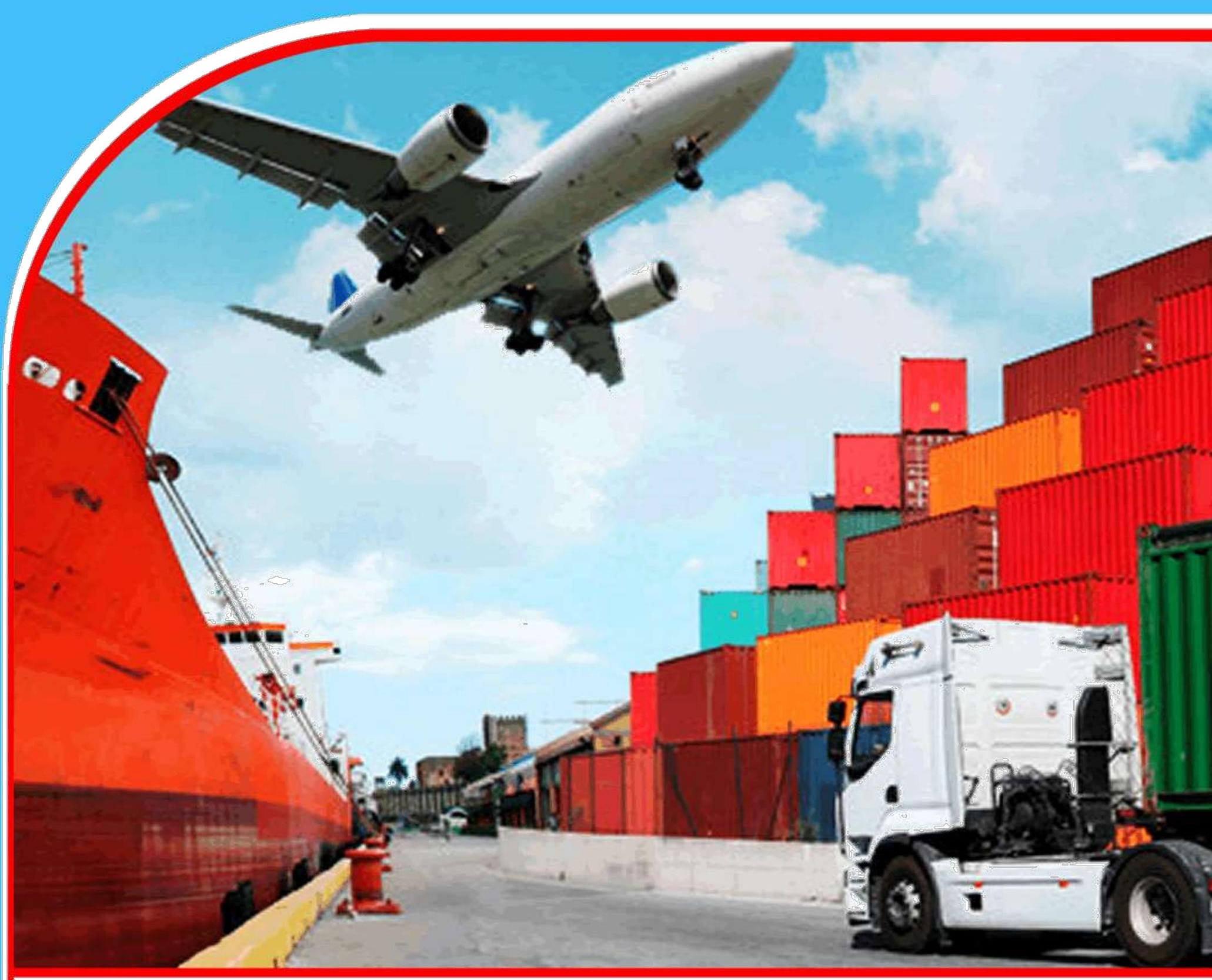

EFFECT OF INTERNAL ENVIRONMENT MANAGEMENT PRACTICES ON SUPPLY CHAIN PERFORMANCE AMONG AGRIMANUFACTURING FIRMS IN RWANDA

Nimpano Desire, Dr. Patrick M. Mulyungi, PhD and Dr. Noor Ismail

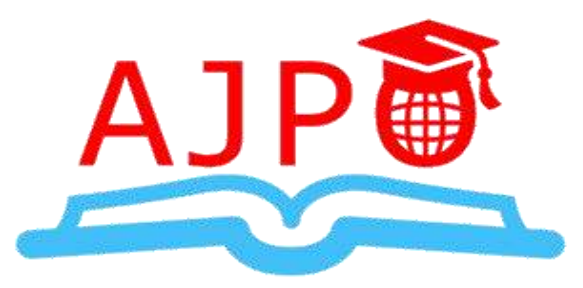




\title{
EFFECT OF INTERNAL ENVIRONMENT MANAGEMENT PRACTICES ON SUPPLY CHAIN PERFORMANCE AMONG AGRI-MANUFACTURING FIRMS IN RWANDA
}

\author{
Nimpano Desire \\ $\mathrm{PhD}$ Student, Jomo Kenyatta University of Agriculture and Technology \\ Dr. Patrick M. Mulyungi, PhD \\ Jomo Kenyatta University of Agriculture and Technology, Kenya \\ Dr. Noor Ismail \\ Jomo Kenyatta University of Agriculture and Technology, Kenya
}

\begin{abstract}
Purpose: The purpose of the study was to determines the effect of Internal Environment Management Practices on Supply Chain Performance among Agri-Manufacturing Firms in Rwanda

Methodology: This study employed both cross-sectional and explanatory research design and is in line with positivism approach. The target population was 567 top and middle employees in supply chain department from 67 Agri-Manufacturing Firms. Stratified and simple random sampling was used to select a sample of 226. This study collected both secondary and primary data, but mainly primary data using a structured questionnaire. Data analysis was performed with the aid of SPSS version 22.0 (Hayes and Matthes, 2009) using both descriptive and inferential statistics. Hypothesis 1 to 4 was tested using multiple regression model, while hypothesis 5 was tested using hierarchical regression.

Results: Findings showed that internal environmental management positively and significantly influences supply chain performance

Unique contribution to Theory and Practice: It is therefore important for both the senior managers and mid - level managers to be committed and supportive of GSCM. Besides that, there is need for the firm to have total quality environmental management and ISO 14001 for environmental compliance. As well, having a team within the firm that is tasked with environmental improvements will go a long way in enhancing supply chain performance.
\end{abstract}

Keywords: Internal environment, management practices, supply chain performance 


\subsection{INTRODUCTION}

Supply chain performance is often a clear indicator and measure of firm performance. The modern-day business operating environment makes it imperative that businesses streamline the efficiency of all the business units that make up the pipeline that ensures the timely delivery of quality products to their clientele (Chen \& Labadi, 2015). The essence of supply chain management is to help companies to have more control over the outcomes of their processes by giving them an active glimpse and influence over the processes of their departments (functional boundaries) and partners (company boundary). While improving communication among the departments (functional units) of a firm is instrumental to improving product design, production and delivery, improving communication with their partners is also an important contributor to business success. It is especially important as the changes in consumer demands and the increasing effects of globalization increase the uncertainties of business operating environments (Abdullah \& Abdel, 2014).

Businesses today are increasingly relying on supply chain management to open up new areas of competitiveness in their processes and the accomplishment of their objectives if they are to exceed consumer needs (Bosman, 2016). The increasing effects of globalization have also made it possible for talent specialization and differentiation making it more cost effective for firms to outsource some functions, such as manufacturing. As such, such businesses have to work to improve their logistics functions and processes to ensure their quality assurance and timely delivery of products. However, this is only possible if companies can develop their supply chain management capacity and ability actively (Van \& Beulens, 2012). Green supply chain is a growing trend among many businesses because of its proven ability to improve the sustainability and practicality of a business's strategy development. However, despite its importance in the performance management of a company's financial and process performance and viability in the Agri-Manufacturing businesses in Rwanda although there is not sufficient data to substantiate these claims (Wegner \& Bode, 2016).

Current trend of supply chain in today's green economy, it has changed a lot in production, packaging and transportation of products. Considering our growing manufacturing companies and green production-oriented policies, all levels of supply chain must be a monitoring stage to make sure that environmental protection is taken into account. The rising current interest and enforcement of environmentally conscious business practices are resulting in more companies changing their business operating strategies to comply with the new standards. A number of scholars have looked into different definitions and conceptualizations of green supply chain management and its implications on business processes and the environment moving into the future. The general consensus is that it involves innovations that ensure a company's purchasing and production units is sustainable and promotes the wellness of its employees, consumers and environment (Sung Rha, 2010). Greening supply chains involves businesses working to achieve a middle ground between the accomplishment of their bottom lines and minding their environment. Therefore, companies have to work on creating business ecosystems that promote the optimization of production and delivery chains to minimize 
wastage and ensure high quality products while increasing the attainment of set goals and objectives (Kumar \& Chandrakar, 2012).

Interior ecological administration is the act of creating green inventory network the board as a vital authoritative basic through responsibility and support of the basic from senior and mid-level chiefs (Green et al, 2010). Inside ecological administration is fundamental to enhancing ventures' natural execution (Melnyk et al., 2002). It is for the most part trusted that senior administrators' help is essential and, frequently, a key driver for fruitful appropriation and usage of most advancements, innovation, projects and exercises (Hamel \& Prahalad, 1989).

Yeung et al., (2003) found that senior administration's certainty is the most powerful factor for the advancement of their quality administration framework. Additionally, cross-utilitarian projects incorporating GSCM and CLSC rehearses are not for the "black out of heart" and require the executives' help for fruitful usage (Matthews, 2004; Seitz and Peatty, 2004). To guarantee advance for ecological administration, top administration must be completely dedicated (Zsidisin \& Siferd, 2001; Rice, 2003).

Bolster needs to likewise exist from mid-level chiefs for fruitful execution of ecological practices (Carter et al., 1998; Bon et al., 2001). GSCM crosses every single departmental limit inside and among associations, and this collaboration and correspondence is essential to fruitful natural practices (Zhu \& Geng, 2001; Aspan, 2000). In this study, the researcher seeks to establish the relationship between internal environment management practices and company performance especially in the long term. It looks at the aspects of both the internal and the external environments of Agri-manufacturers in a bid to attain a mix that promotes both high performance and good corporate responsibility. Thus, this study hypothesized that;

$H_{0:} \quad$ There is no significant effect of internal environment management practices on supply chain performance among Agri-Manufacturing Firms in Rwanda

\subsection{LITERATURE REVIEW}

\subsection{Institutional Theory}

The institutional theory sets that endeavors grasp certain procedures so as to pick up authenticity or acknowledgment inside society (Zhu and Sarkis, 2007). The hypothesis investigates the impact on a firm by outside weights (Hirsch, 1975). DiMaggio and Powell (1983) pinpoint three channels through which isomorphic change happens. These incorporate; coercive, mimetic and regularizing weights. Coercive weights happen through the impact of people with great influence (Zhu \& Sarkis, 2007).

For instance, governments' impact how associations act by ordering directions which the organizations are relied upon to hold fast to (Rivera, 2004). The dread of repercussions for rebelliousness makes firms take part in proactive natural practices. Darnall et al. (2008) contend that in a few occurrences, administrative weights for firms to actualize

GSCM practices can make open doors for upper hand. Thus, nearby firms that serve 
worldwide markets have been compelled to embrace thorough ecological models with the end goal for them to remain focused.

Mimetic weights happen when an association imitates the activities of fruitful rivals in the business (Zhu \& Sarkis, 2007). Mimetic weights is a primary driver for firms to actualize GSCM rehearses. As an outcome of globalization, firms in creating nations can learn through self-direction, from their outside rivals in created nations on the best way to execute natural administration rehearses (Christmann \& Taylor, 2001).

Regulating weights are advanced by outer partners who have personal stake in the firm (Zhu \& Sarkis, 2007). These partners incorporate clients, social gatherings, investors and providers. Firms that respect these weights are seen to be progressively real. Sarkis et al. (2011) distinguish the client as the center regulating weight to makers to execute GSCM rehearses. Natural and local gatherings draw the general population's consideration on the negative ecological impacts of firms' tasks by driving dissents and blacklists. Worker's organizations additionally put weight on these organizations so as to guarantee the security of their association individuals from damage that may result from ecological mishaps. Likewise, exchange affiliations have started to play an increasingly dynamic job in dealing with their individuals' natural activities (Darnall et al., 2008). Another dimension of institutional weight may originate from its investors (Henriques \& Sadorsky, 1996). A firm with a decent natural notoriety is probably going to draw in speculators. Henriques and Sadorsky (1999) include that earth cognizant providers may avoid firms that are not naturally cognizant so as to secure their own notoriety.

Zhu and Sarkis (2007) contend that institutional weights may make firms participate in proactive natural practices, for example, GSCM. Firms that respect these weights are seen to be increasingly authentic and are probably going to increase upper hand and consequently enhanced hierarchical execution (Zhu \& Sarkis, 2007; Darnall et al., 2008).

\subsection{Empirical review}

Srivastava (2007) expressed that Green Supply Chain Management is a base of both ecological administration and production network the executives. The commitment of inner ecological administration improves the relationship among the inventory network the board practices and regular habitat. Hevani et al., (2005) portray that store network the executives is a mind boggling system including coordination and the board exercises including in to convey a completed item to the end client. Srivastava (2007) expressed that the existence cycle appraisal/examination and naturally cognizant plan of the item clarify in the writing. A hierarchic structure for ecologically cognizant plans are introduced by Madu et al., (2002). Inner ecological administration is a vital territory in green production network activity.

Lakshmimeera and Palanisamy (2013) merged a paper on a Conceptual Framework on Green Supply Chain Management rehearses for Indian Manufacturing industry. They reason that inner natural administration can enhance aggressiveness and ecological execution prompting manageability. Chien (2014), clarify the impacts of inner ecological administration on authoritative feasible execution and found that Green Supply Chain 
Management polished by Taiwan Electrical and Electronic producers and will decidedly influence the financial, natural, and social exhibitions.

\subsection{METHODOLOGY}

This study employed explanatory research design as it seek to describe. The study adopted explanatory design since it uses theories and hypothesis to account for the forces that caused a certain phenomenon to occur (Cooper \& Schindler, 2011). This study was in line with positivism approach, which seeks to use existing theory to deduce and formulate variables, assume hypotheses that are tested and established wholly, in part, or otherwise refuted leading to further development of theory to be tested with future research. The study applied cluster and simple random sampling proportionate to the cluster size. According to MaCorr Research Solutions (2014) calculations, a sample population of 567 firms results in 226 as respondents. Primary data was collected using a structured questionnaire whereby three questionnaires was given to each of the sampled manufacturing firms' to generate qualitative data, in order to achieve the study objectives.

Data analysis was performed with the aid of SPSS version 22.0 (Hayes \& Matthes, 2009) using both descriptive and inferential statistics. Descriptive analysis was done for comparison of means, frequency distribution, standard deviation, skewness and Kurtosis values and is discussed as follows. Model 1 below sought to establish effect of control variables and direct effects of GSCM dimensions variables against supply chain performance respectively.

$y=\beta_{0}+C+\varepsilon$

Model 1

$F P=\beta_{0}+C+\beta_{1} x_{1}+\varepsilon$ Model 2

Where:-

$\mathrm{Y}$ is dependent variable (Agri-Manufacturing firm's supply chain performance)

$\mathrm{X} 1$ is independent variable \# 1 (internal environment management)

$\mathrm{C}$ is control variable

$\beta 0$ is a constant

$\varepsilon$ is Error term (random variation due to other unmeasured factors).

\subsection{FINDINGS AND DISCUSSIONS}

Reliability analysis was carried out using Cronbach alpha which is a coefficient of reliability that gives an unbiased estimate of data generalizability. Out of which 220 questionnaires from 226 were returned. However, of the 220 returned, a total of 212 were reasonably and adequately completed representing approximately $93.8 \%$ response rate. Cronbach Alpha was established for every objective which formed a scale. The table below shows that internal environment management had cronbach alpha value of $\alpha=0.655)$. Other than internal environment management, the other scales were reliable as their reliability values exceeded the prescribed threshold of 0.7 . 


\subsection{Sample Characteristics}

From the results,32.7\% (70) of the respondents noted that the firms have been in operation for a period ranging a year to 3 years, $27.6 \%$ (59) for 4 to 7 years, $24.3 \%$ (52) for over 15 years and $7.5 \%$ (16) for 8 to 11 years. On average, most of the firms have been in operation for a period ranging from a year to seven years. As a result, the firms are likely to have better supply chain performance because they are more experienced and enjoy the benefits of "learning by doing" (Coad et al. 2013, Vassilakis 2008).

Firm size was measured by assessing the number of employees in the firms as shown in table 4.5. From the results, $63.1 \%$ (135) of the respondents noted that their firm has between 1 to 100 employees, 21\% (45) between 101 to 200 employees, 9.8\% (21) between 201 to 300 employees while $6.1 \%$ (13) of the respondents stated that their firm has between 301 to 400 employees. Generally, most of the firms are small as evidenced by employees ranging from 1 to 100.Since the firms are small, it could be that they lack the market power possessed by large firms in charging higher prices thereby earning more profits. They could also lack stronger negotiating power that provides larger firms more favorable financing conditions.

\subsection{Descriptive Statistics for Study Constructs}

Respondents were asked to provide information regarding their level of agreement to items concerning internal environment management, green purchasing, eco-design, investment recovery, institutional pressure and supply chain performance.

\subsubsection{Internal Environment Management}

The study deemed it important to establish the effect of internal environment management practices on supply chain performance among Agri-Manufacturing Firms in Rwanda. Table 4.8 highlights the results. Basing on the results, the firm senior managers are committed to GSCM (Mean $=4.51, \mathrm{SD}=0.551$ ). In that way, top management support is a step further towards ensuring that there is commitment to GSCM. Other than that, there is also support for GSCM from the mid - level managers (mean $=3.94, \mathrm{SD}=$ 0.882).

Besides, the firm has teams responsible for environmental improvements (mean $=4.05$, $\mathrm{SD}=0.732$ ). The implication is that there is special dedication to environmental improvement by the firms which is key in ensuring the attainment of superior green supply chain management. Moreover, the firm has total quality environmental management $($ mean $=4.24, \mathrm{SD}=0.799)$. On the same note, there is ISO 14001 certification for complying with environmental compliance and auditing programs (mean $=4.00, \mathrm{SD}=0.884$ ). The results suggest that the firms in question comply with the quality standards pertaining environmental management. In addition, the firm supports environmental regulations (mean $=4.04, \mathrm{SD}=0.561$ ). The only challenge is that there is no emphasis on Eco labeling of products (mean $=2.56, \mathrm{SD}=1.409)$. This is an area that needs urgent attention if supply chain performance is to be enhanced. 
Table 1: Internal Environment Management

\begin{tabular}{|c|c|c|c|c|}
\hline $\mathrm{N}=214$ & Mean & $\begin{array}{l}\text { Std. } \\
\text { Dev. }\end{array}$ & Skewness & Kurtosis \\
\hline $\begin{array}{l}\text { The firm senior managers are } \\
\text { committed to GSCM }\end{array}$ & 4.51 & 0.551 & -0.704 & 0.58 \\
\hline $\begin{array}{l}\text { The firm mid-level managers support } \\
\text { for GSCM }\end{array}$ & 3.94 & 0.882 & -0.828 & 1.165 \\
\hline $\begin{array}{l}\text { The firm has teams responsible for } \\
\text { environmental improvements }\end{array}$ & 4.05 & 0.732 & -0.73 & 1.758 \\
\hline $\begin{array}{l}\text { The firm has total quality } \\
\text { environmental management }\end{array}$ & 4.24 & 0.799 & -1.257 & 2.323 \\
\hline $\begin{array}{l}\text { The firm has ISO } 14001 \text { certification } \\
\text { for complying with environmental } \\
\text { compliance and auditing programs }\end{array}$ & 4.00 & 0.884 & -0.308 & -1.027 \\
\hline $\begin{array}{l}\text { The firm has environmental } \\
\text { management systems } \\
\text { the firm emphasizes for Eco-labeling }\end{array}$ & 3.92 & 0.936 & -0.61 & -0.283 \\
\hline of Products & 2.56 & 1.409 & 0.266 & -1.388 \\
\hline $\begin{array}{l}\text { The firm support for environment } \\
\text { regulations }\end{array}$ & 4.04 & 0.561 & -0.709 & 1.165 \\
\hline Internal environment management & 3.8777 & 0.4835 & -0.868 & 2.17 \\
\hline
\end{tabular}

Overall, the findings on internal environment management summed up to a mean of 3.8777 , standard deviation of 0.48356 , skewness of -0.868 and kurtosis of 2.17 . The implication is that the respondents were agreeable on most of the items on internal environment management. There was also less variations in the responses as indicated by the standard deviation. The extant literature has also indicated that programs encompassing GSCM and CLSC practices are not for the faint hearted hence the need for top management support for successful implementation (Matthews, 2004; Seitz and Peatty, 2004). Similarly, the literature has indicated that the top management must be fully committed if progress is to be realized in environmental management. As well, support from the mid - level managers are key in the implementation of environmental practices (Carter et al.,1998; Bon et al.,2001).

\subsubsection{Supply chain performance}

This section of the analysis highlights the results on supply chain performance. Basing on the findings in table 4.15, the firms have the ability to customize product to meet specific customer demand (mean $=4.03, \mathrm{SD}=0.779$ ). Besides, the firm has customer responsiveness flexibility (mean $=4.18, \mathrm{SD}=0.816$ ). Moreover, the firm has low percentage of defects (mean $=4.05, \mathrm{SD}=0.624$ ) and high percentage of finished goods in transit $($ mean $=4.05, \mathrm{SD}=0.804)$. However, there is no efficiency of purchase order 
cycle time (mean $=1.07, \mathrm{SD}=0.259)$. Generally, the findings on supply chain performance summed up to a mean of 3.6878 , standard deviation of 0.42973 , skewness 0.736 and kurtosis 1.007 .

Table 2: Supply Chain Performance

\begin{tabular}{lcccc}
\hline N=214 & $\begin{array}{c}\text { Mea } \\
\text { n }\end{array}$ & $\begin{array}{c}\text { Std. } \\
\text { Deviation }\end{array}$ & $\begin{array}{c}\text { Skewn } \\
\text { ess }\end{array}$ & $\begin{array}{c}\text { Kurto } \\
\text { sis }\end{array}$ \\
\hline The ability to customize product to meet specific & & & & \\
customer demand & 4.03 & 0.779 & -0.94 & 1.093 \\
The firm has customer responsiveness flexibility & 4.18 & 0.816 & -0.433 & -1.117 \\
The firm has low percentage of defects & 4.05 & 0.624 & -0.168 & 0.046 \\
The firm has high percentage of finished goods in & & & & \\
transit & 4.05 & 0.804 & -0.33 & -0.455 \\
There is efficiency of purchase order cycle time & 1.07 & 0.259 & 3.33 & 9.14 \\
& 3.68 & & & \\
Supply chain performance & 78 & 0.42973 & -0.736 & 1.007 \\
\hline
\end{tabular}

\subsection{Hypothesis testing (regression and correlation analysis)}

A Pearson correlation analysis was conducted to investigate whether there is relationship between the dependent variable (Supply Chain performance) and internal environment management,. The analysis revealed that there was a positive relationship between the dependent variable and independent variable since The correlation between internal environment management and supply chain performance was significant, $\mathrm{r}=0.684, \mathrm{P}<$ 0.01. Regression is one of the pertinent and commonly used statistical method in research. It provides a platform for which causal-effect relationships among variables of interest in the study are examined. Hence, it provides a method for quantifying the effect of changes in the response variable as a result of change in predictor variables (Darlington \& Hayes, 2016; Mills \& Tosic, 2011; Hair et al., 2010). Therefore, regression analysis was performed to test the model fit and to establish the predictive power of the models in the response variable.

$H_{01}$ There is no significant effect of internal environment management practices on supply chain performance among Agri-Manufacturing Firms in Rwanda

The first hypothesis of the study stated that there is no significant effect of internal environment management practices on supply chain performance among Agrimanufacturing firms in Rwanda. However, findings in table 4.27 showed that internal environment management practices had coefficients of estimate which was significant basing on $\beta_{1}=0.624$ ( $\mathrm{p}$-value $=0.000$ which is less than $\alpha=0.05$ ) thus we reject the null hypothesis and conclude that internal environment management practices have a significant effect on supply chain performance. This suggests that there is up to 0.624unit increase in supply chain performance for each unit increase in internal environment 
American Journal of Supply Chain Management ISSN 2518-4709 (online)

Vol.4, Issue 1 No.1, pp 1 - 12, 2019 www.ajpojournals.org

management practices. Also, the effect of internal environment management practices is more than the effect attributed to the error, this is indicated by the t-test value $=11.640$.

Table 4.27 further illustrates the model summary of multiple regression model, the results showed that internal environment management practices explained 39 percent variation of supply chain performance. This showed that considering internal environment management practices, there is a probability of predicting supply chain performance by $39 \%$ ( $\mathrm{R}$ squared $=0.39$ ). Finally, study findings in the table indicated that the above discussed coefficient of determination was significant as evidence of $F$ ratio of 135.491 with $\mathrm{p}$ value $0.000<0.05$ (level of significance).

Consistent with the results, Lakshmimeera \& Palanisamy (2013) posited that internal environmental management is key in enhancing competitiveness and environmental performance which in turn lead to sustainability. Similarly, Yeung et al., (2003) confirmed that senior management confidence is the most influential factor for the development of quality management system.

Table 3: Effect of Internal Environment Management on Supply Chain Performance

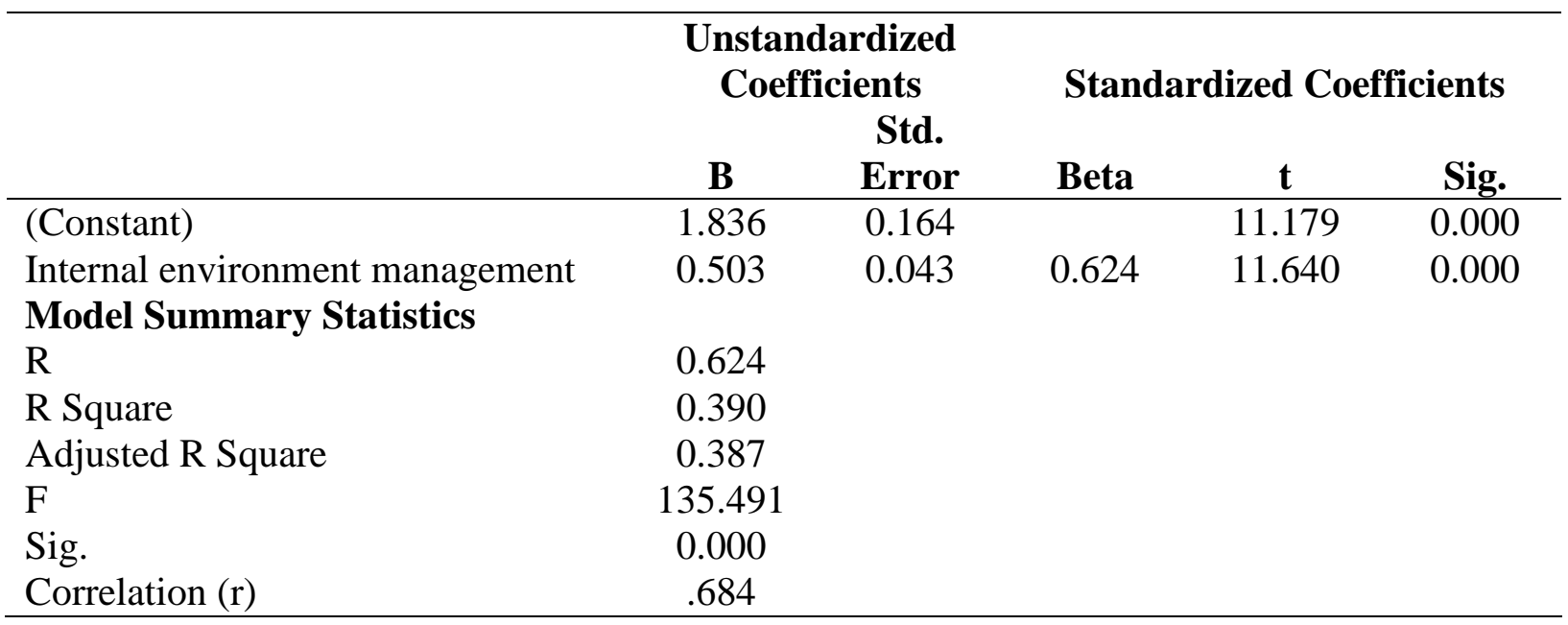

\subsection{CONCLUSION AND RECOMMENDATION}

\subsection{Conclusion}

In conclusion, internal environmental management positively and significantly influences supply chain performance. The implication is that support from the top management is extremely essential in the implementation as well as the adoption of green supply chain management. Without the presence of senior managers, GSCM is bound to fail. Not only do the senior management enhance GSCM but they also enhance the relationships among the supply chain management practices and natural environment. Therefore, for 
American Journal of Supply Chain Management ISSN 2518-4709 (online)

Vol.4, Issue 1 No.1, pp 1 - 12, 2019

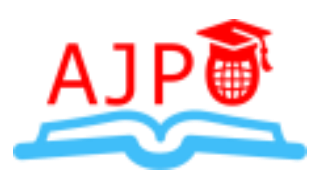

www.ajpojournals.org

manufacturing firms to exhibit superior supply chain performance, the commitment and support from both the mid - level and senior-level management is crucial.

\subsection{Recommendations}

Basing on the study findings, internal environmental management is key in the attainment of improved supply chain performance by manufacturing firms. It is therefore important for both the senior managers and mid - level managers to be committed and supportive of GSCM. Besides that, there is need for the firm to have total quality environmental management and ISO 14001 for environmental compliance. As well, having a team within the firm that is tasked with environmental improvements will go a long way in enhancing supply chain performance.

This study expands our knowledge on effects of green supply chain adoption on supply chain performance: survey of Agri-Manufacturing Firms in Rwanda. Though this study has fulfilled its aim and objectives, and there are a number of areas for additional studies and empirical research, given the limitations of the research.

On a geographical dimension, this study was primarily limited to Agri-Manufacturing Firms in Rwanda. Therefore, it may not be appropriate to generalize to the whole population of firms in Rwanda or any other country. For this reason, further empirical investigations in different regions and countries are needed.

\section{REFERENCES}

Abdullah, Z., \& Abdullah, A. H. (2014). Performance determinants for convenience store suppliers. Journal of World Academy of Science, Engineering and Technology, 68, pp 2129-2134

Aspan, H., 2000. Running in nonconcentric circles: why environmental management isn't being integrated into business management. Environmental Quality Management 9 (4), 69-75

Carter, C. R., \& Ellram, L. M. (1998). Reverse logistics: a review of the literature for future investigations. Journal of Business Logistics. 19(1), 85-102.

Chen, H.X., Amodeo, L., Chu, F., \& Labadi, K. (2015). Modelling the performance evaluation of supply chains using batch deterministic and stochastic Petri nets. IEEE Transactions on Automated Science and Engineering, 2(2), 78-85.

Chien, M. K., \& Shih, L. H. (2014). An empirical study of the implementation of green supply chain management practices in the electrical and electronic industry and their relation to organizational performances. International Journal of Environmental Science and Technology, 4(3), 383-394.

Christmann, P., \& Taylor, G. (2001). Globalization and the environment: Determinants of firm self-regulation in China. Journal of International Business Studies, 32(3), 439458. 
Cooper, D.R., \& Schindler, P.S. (2011). Business research methods, (11 195 th, ed.). New Delhi: McGraw-Hill Publishing, Co. Ltd

Darnall, N., Henriques, I., \& Sadorsky, P. (2008). Do environmental management systems improve business performance in an international setting? Journal of International Management, 14(4), 364-376.

Darnall, N., Jolley, G. J. and Handfield, R., (2008). Environmental management systems and green supply chain management: complements for sustainability?, Business Strategy and the Environment, 18,30-45.

DiMaggio, P. I., \& Powell, W. W. (1983). The iron cage revisited: Institutional isomorphism and collective rationality $\mathrm{m}$ organizational fields. American Sociological Review, 48, 147-160.

Green K. W., Zelbst, P. J., Meacham, J., \& Bhadauria, V. S. (2010). Green supply chain management practices: impact on performance. Supply Chain Management: $A n$ International Journal, 17(3), 290-305.

Hair Jr., J. F., Black, W. C., Babin, B. J., \& Anderson, R. E. (2010). Multivariate data analysis: A global perspective. (7th ed.). Upper Saddle River, New Jersey, USA: Pearson Education, Inc.

Hamel, G., Prahalad, C.K., 1989. Strategic intent. Harvard Business Review 67, 63-76

Harrison, J. S., Hitt, M. A., Hoskisson, R. E., \& Ireland, R. D. (2001). Resource complementarity in business combinations: Extending the logic to organizational alliances. Journal of Management, 27(6), 679-690.

Hayes, A. F., \& Matthes, J. (2009). Computational Procedures for Probing Interactions in OLS and Logistic Regression SPSS and SAS Implementations

Henriques, I., \& Sadorsky, P. (1996). The determinants of an environmentally responsive firm: an empirical approach. Journal of Environmental Economics and Management, 30(3), 381-395.

Hirsch, P. M. (1975). Organizational effectiveness and the institutional environment. Administrative Science Quarterly, 327-344.

Kumar, S., Chattopadhyaya, S. and Sharma, V., (2012), Green supply chain management: A case study from Indian electrical and electronics industry, International Journal of Soft Computing and Engineering , 1(6), 275-281.

Lakshmimeera, B.L. and Palanisamy, C. (2013), "A Conceptual Framework on Green Supply Chain Management Practices" Industrial Engineering Letters, Vol.3, No.10, 42-52.

Madu, C.N., and Madu, A.A. "Dimensions of E-quality", International Journal of Quality and Reliability Management (19:3) 2002, pp 246-258.

Matthews, S., 2004. Thinking outside the 'box': designing a packaging take-back system. California Management Review 46 (2), 105-119. 
Melnyk, S.A., Sroufe, R.P., Calatone, R., 2002. Assessing the impact of environmental management systems on corporate and environmental performance. Journal of Operations Management 21 (2), 329-351.

Rha Jin Sung, (2010), The Impact of Green Supply Chain Practices on Supply Chain Performance. Unpublished MA, University of Nebraska at Lincoln Available at http://digitalcommons.unl.edn/businessdiss/l 1

Rice, S., 2003. Commitment to excellence: Practical approaches to environmental leadership. Environmental Quality Management 12 (4), 9-22

Rivera, J. (2004). Institutional pressures and voluntary environmental behavior in developing countries: Evidence from the Costa Rican hotel industry. Society and Natural Resources, 17(9), 779-797

Sarkis, J., Zhu, Q., \& Lai, K. H. (2011). An organizational theoretic review of green supply chain management literature. International Journal of Production Economics, 130(1), 1-15

Seitz, M.A., Peatty, K., 2004. Meeting the closed-loop challenge: the case of remanufacturing. California Management Review 46 (2), 74-89

Srivastava, S. K. (2007). Green supply-chain management: a state-of-the-art literature review. International Journal of Management Reviews, 9(1), 53-80.

Yeung, A.C.L., Lee, T.S., Chan, L.Y., 2003. Senior management perspectives and ISO 9000 effectiveness: an empirical research. International Journal of Production Research 41 (3), 545-569

Zhu, Q., \& Sarkis, J. (2007). The moderating effects of institutional pressures on emergent green supply chain practices and performance. International Journal of Production Research, 45(18-19), 4333-4355.

Zhu, Q., Geng, Y., 2001. Integrating environmental issues into supplier selection and management: A study of large and medium-sized state-owned enterprises in China. Greener Management International Autumn, 27-40

Zhu, Q., Sarkis, J., \& Lai, K. H. (2007). Initiatives and outcomes of green supply chain management implementation by Chinese manufacturers. Journal of Environmental Management, 85(1), 179-189.

Zsidisin, G.A. and Siferd, S.P. (2001) "Environmental purchasing: a framework for theory development', European Journal of Purchasing and Supply Management, Vol. 7, No. 1, pp.61œ73. 